Original Research Paper

\title{
Kapasitas Adaptif Mangrove Pada Pulau Kecil Mikro Studi Di Pulau Maitara Kota Tidore Kepulauan Propinsi Maluku Utara
}

\author{
Riyadi Subur ${ }^{*}$, Sarni $^{2}$ \\ ${ }^{1}$ Program Studi Manajemen Sumberdaya Perairan, FPIK-Universitas Khairun \\ ${ }^{2}$ Program Studi Agroteknologi, Fakultas Pertanian- Universitas Khairun
}

Article history

Received: 11 Juli 2018

Revised: 28 Agustus 2018

Accepted: 2 Oktober 2018

Published: 21 November 2018

*Corresponding Author:

Riyadi, Program Studi

Pendidikan Biologi FKIP

Universitas Mataram,

Indonesia

Email:

riyadisubur58@gmail.com

\section{Pendahuluan}

Mangrove adalah ekosistem pesisir transisi yang unik, tumbuh diantara lingkungan laut dan terestrial, secara umum, penyebarannya terbatas pada daerah tropis dan sub-tropis di seluruh dunia (Bayen, 2012). Menyediakan berbagai layanan ekologi dan sosial (Moberg dan Ronnback, 2003; Walters et al., 2008; Castilo et al., 2017).

\begin{abstract}
Mangroves are unique transitional coastal ecosystems, growing between marine and terrestrial environments, the spread is generally limited to tropical and subtropical regions around the world. Providing a variety of ecological, economic and social services. Effectively serves as a protector coastal land of small island. The purpose of this study is to determine the adaptive capacity of mangrove ecosystems on Maitara Island. This research was conducted using the Mangrove Ecosystem Adaptive Capacity Measurement method. The results of this study found as many as 4 mangrove species, that is Rhizophora apiculata, $R$. mucronata, $R$. stylosa and Soneratia alba, consisting of 2 genera, Rhizophora, and Sonneratia. Dominance index value is 0.57 , moderate dominance by $R$. apiculata. Tree density per hectare is 789 stands. The value of the adaptive capacity of the mangrove ecosystem on the island of Maitara is 0.44 , which means that the island's mangrove adaptive capacity is "medium".
\end{abstract}

Keywords:Adaptive Capacity, Mangrove, Micro-Small Island

Abstrak: Mangrove adalah ekosistem pesisir transisi yang unik, tumbuh diantara lingkungan laut dan terestrial, penyebaran umumnya terbatas pada daerah tropis dan subtropis di seluruh dunia. Menyediakan berbagai layanan ekologi, ekonomi serta sosial. Efektif berfungsi sebagai pelindung lahan daratan pesisir pulau kecil. Tujuan penelitian ini adalah untuk mengetahui kapasitas adaptif ekosistem mangrove di pulau Maitara. Penelitian ini dilakukan dengan metode Pengukuran Kapasitas Adaptif Ekosistem Mangrove. Hasil penelitian ini ditemukan sebanyak 4 spesies mangrove yaitu, Rhizophora apiculata, R. mucronata, $R$. stylosa dan Soneratia alba, terdiri dari 2 genera, Rhizophora, dan Sonneratia. Nilai indeks dominasi sebesar 0,57 , dominasi sedang oleh $R$. apiculata. Kerapatan pohon per hektar sebanyak 789 tegakan. Nilai kapasitas adaptif ekosistem mangrove di pulau Maitara sebesar 0,44, yang berarti bahwa kapastias adaptif mangrove pulau tersebut"sedang".

Kata kunci: Kapasitas Adaptif, Mangrove, Pulau Kecil-Mikro

Ekosistem ini juga dijadikan sebagai daerah asuhan bagi organisme laut, tempat memijah ikan, tempat bersarang dan berkembang biak bagi burung, reptil, mamalia, krustacea, sebagai sumberdaya kayu terbarukan, tempat akumulasi sedimen, bahan organik (Twilley, 1995; Kathiresan dan Bingham, 2001; Manson et al., 2005), berfungsi secara ekologi antara lain, konservasi keanekaragaman hayati (biodiversity), memberi perlindungan 
terhadap badai, pengaturan sedimen, dan stabilisasi pantai (Koch et al., 2009; Barbier et al., 2011; Salmo et al., 2013). Di negara-negara berkembang, ekosistem mangrove memegang peranan penting bagi kehidupan manusia, terutama yang berhubungan dengan mata pencaharian (Alongi, 2002). Mangrove juga digunakan secara tradisional oleh masyarakat sebagai bahan makanan, bahan bakar serta obat-obatan (Saenger, 2002).

Mangrove merupakan satu dari tiga ekosistem pesisir utama yang cukup efektif berfungsi sebagai pelindung terhadap keselamatan lahan daratan pulau-pulau kecil (Moberg, dan Folk, 1999). Memberikan perlindungan dari arus pasang surut, tsunami serta dapat meredam erosi garis pantai (Mazda et al., 2007). Namun menurut FAO (2007), sebanyak $20 \%$ dari total daerah mangrove telah hilang sejak tahun 1980. Valiela et al., (2001), setidaknya $35 \%$ dari luas wilayah itu hilang antara tahun tahun 1980 sampai tahun 2000. Kerugian ini disebabkan oleh berbagai tekanan antropogenik, seperti pertumbuhan populasi manusia, konversi mangrove menjadi tambak untuk budidaya perairan, pertanian, pembangunan perkotaan atau permukiman, pariwisata, tekanan iklim, termasuk naiknya permukaan air laut dan tsunami, menyebabkan penurunan luasannya (Duke et al., 2007; Alongi, 2008; UNEP, 2014; Webb et al., 2014). Mangrove menyediakan jasa ekosistem berharga yang bermanfaat bagi masyarakat pesisir, termasuk stabilisasi tanah pantai dan perlindungan badai (Walters et al., 2008). Secara fisik peran ekosistem tersebut adalah sebagai pencegah erosi, perangkap sedimen serta penghalang gelombang serta arus air laut. Keberadaan ekosistem tersebut pada suatu wilayah pesisir dan pulau-pulau kecil, berperan penting dalam meningkatkan kapasitas adaptif suatu pulau terhadap bencana alam karena berfungsi sebagai pelindung alami (Mimura, 1999).

Kapasitas adaptif adalah kemampuan suatu sistem untuk menyesuaikan diri terhadap suatu gangguan atau potensi kerusakan (Gallopin, 2006). Selanjutnya Fusel and Klien (2006), menambahkan bahwa kapasitas adaptif sebagai kemampuan dari suatu sistem untuk melakukan penyesuaian terhadap suatu perubahan yang menyebabkan potensi dampak mejadi lebih moderat, mengambil manfaat untuk mengatasi konsekuwensi yang ditimbulkan akibat perubahan tersebut. Luers (2005), mengemukakan bahwa kapasitas adaptif memiliki potensi untuk menggeser posisi sistem pada permukaan kerentanan tinggi ke tingkat kerentanan yang lebih rendah dengan mengurangi sensitivitas (sensitivity), dan keterbukaan (exposure), sehingga apabila kapasitas adaptif yang dimiliki oleh suatu sistem itu rendah, maka sistem tersebut cenderung memiliki kerentanan yang tinggi.

Maitara adalah salah satu pulau kecil mikro, dengan luas 270 hektar, ketinggian dari permukaan air laut $340 \mathrm{mdpl}$. Pulau ini berada diantara gunung api "Gamalama" di pulau Ternate dan gunung api "Kie Matubu" di pulau Tidore. Manusia mendiami daerah dataran rendah pada bagian utara, timur dan selatan, dari pulau tersebut. Yang dimaksud dengan pulau kecil- mikro dalam penelitian ini yaitu pulau dengan panjang garis pantai kurang atau sama dengan 12000 meter $(\leq 12$ $\mathrm{km})$.

Ekosistem mangrove di pulau Maitara ditemukan menyebar terbatas pada bagian utara serta selatan dari pulau itu, namun demikian keberadaannya saat ini mulai mengalami tekanan, terutama diakibatkan oleh aktivitas manusia (penduduk) yang mendiami pulau Maitara. Konversi lahan hutan mangrove menjadi pemukiman serta penimbunan untuk pembangunan jalan, turut meningkatkan tekanan terhadap ekosistem tersebut, disisi lain keberadaan ekosistem mangrove berperan penting dalam melindungi dataran rendah pesisir pulau Maitara dari hempasan ombak serta arus air laut.

Penelitian tentang kapasitas adaptif ekosistem mangrove di Maluku Utara sebelumnya telah dilakukan pada pulau-pulau keci di kecamatan Kayoa (Subur, 2012), pulau Guraici (2017). Mengingat pentingnya peranan ekosistem mangrove bagi pulau kecil mikro sebagaimana pulau Maitara, maka penelitian ini dilakukan dengan tujuan "Mengetahui kapasitas adaptif ekosistem mangrove di pulau Maitara".

\section{Metode Penelitian}

\section{Tempat}

Penelitian ini dilaksanakan di pulau Maitara pada dua (2) stasiun. Stasiun pertama di bagian utara pada koordinat $0^{\circ} 44^{\prime} 24.11^{\prime \prime}$ Lintang Utara, dan $127^{\circ} 21^{\prime} 55.90^{\prime \prime}$ Lintang Selatan. Stasiun 
kedua di bagian selatan pada koordinat $0^{\circ} 43^{\prime} 38.97^{\prime \prime}$ Penentuan koordinat menggunakan Garmin Lintang Utara, dan $127^{\circ} 27^{\prime} 34.75^{\prime}$ " Lintang Selatan. GPSmap 76CSx, (Gambar 1).

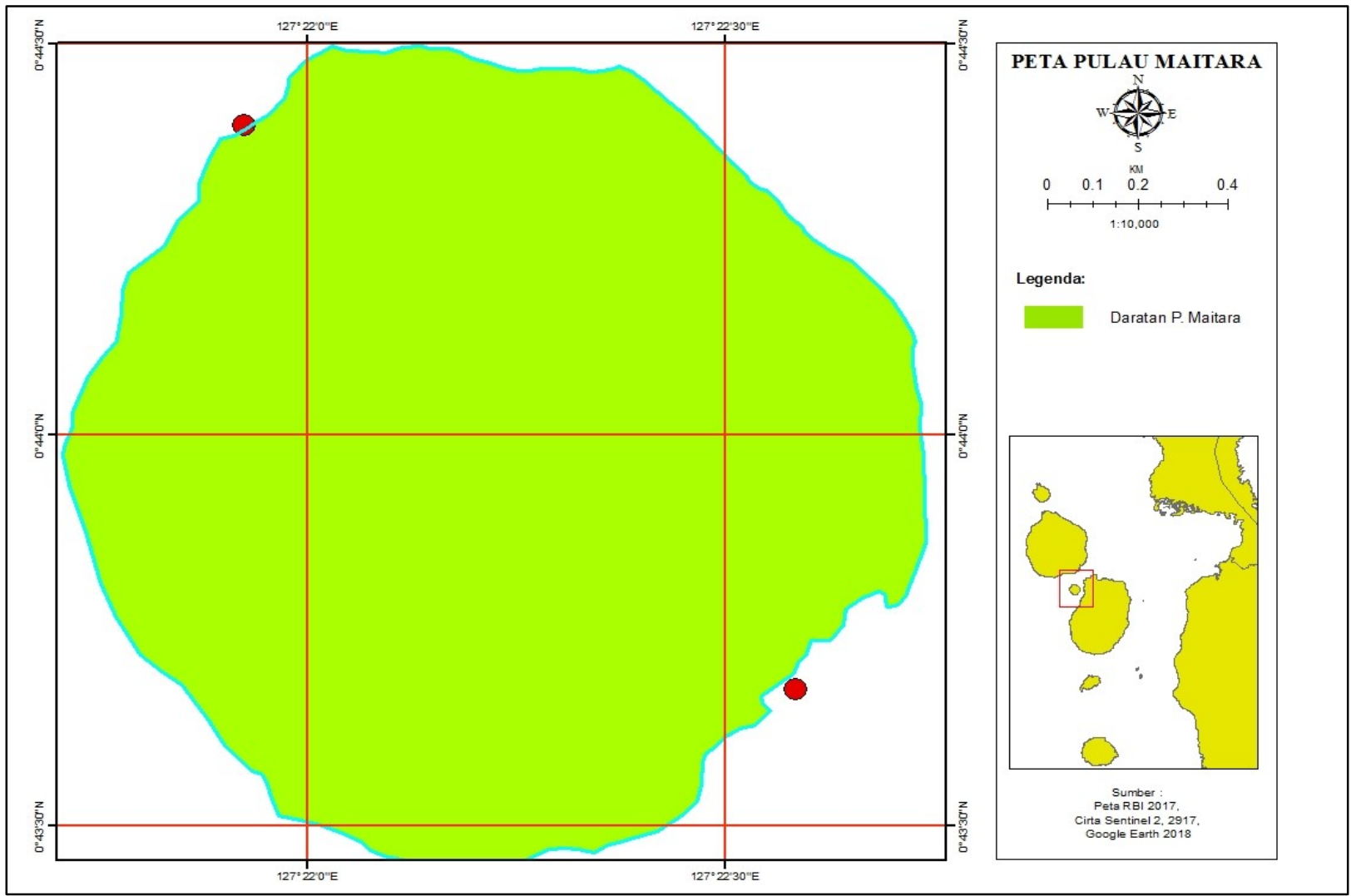

Gambar 1. Peta Lokasi Penelitian

\section{Teknik Pengumpulan Data}

Pengumpulan data dilakukan langsung di lapangan dengan menggunakan metode garis transek (line transect) dengen teknik sampling kuadrat, serta analisis GIS (Geographic information system). Pengumpulan data kapasitas adaptif ekosistem mangrove, meliputi 1 . Indeks dimensi mangrove, bobot (5), 2. Spesies Mangrove Dominan, bobot (5), 3. Kerapatan pohon mangrove per hektar, bobot (3), 4. Jumlah Genera, bobot (3), 5. tipe substrat, bobot (1), 6. Jarak ekosistem dari pemukiman penduduk, bobot (1). Paramater-parameter tersebut tergolong ke dalam 5 kategori berskala ordinal yaitu "Sangat rendah (1)", "Rendah (2)", "Sedang (3)", Tinggi (4)", Sangat tinggi (5)". Nilai Maksimal dari seluruh parameter tersebut adalah $90 \quad\left(\mathrm{~N}_{\max }: 90\right)$. Nilai Maksimal diperoleh dengan mengalikan bobot dari setiap parameter dengan nilai skala/skor tertinggi (Tabel $1)$.

Tabel 1. Parameter pengukuran kapasitas adaptif ekosistem mangrove (Subur, 2012).

\begin{tabular}{|c|c|c|c|c|c|c|c|}
\hline \multicolumn{2}{|c|}{ No. Parameter } & Bobot & $\begin{array}{l}\text { Skala/ Skor } \\
1 \\
\text { Sangat rendah }\end{array}$ & $\begin{array}{l}2 \\
\text { Rendah }\end{array}$ & $\begin{array}{l}3 \\
\text { Sedang } \\
\end{array}$ & $\begin{array}{l}4 \\
\text { Tinggi }\end{array}$ & $\begin{array}{l}5 \\
\text { Sangat tinggi } \\
\end{array}$ \\
\hline 1 & $\begin{array}{l}\text { Indeks Dimensi } \\
\text { Mangrove (IDMg) }\end{array}$ & 5 & $0.0 \leq \mathrm{IL}$ & $40.4<$ & 80.8 & 20.2 & $61.6<\mathrm{IL}$ \\
\hline 2 & Spesies Dominan & 5 & $\begin{array}{l}\text { Ceriops / } \\
\text { Nypa }\end{array}$ & Bruguieria & Rhizopora & Soneratia & Avicenia \\
\hline 3 & Kerapatan (pohon/ ha) & 3 & $<110$ & $110-<330$ & $330-<660$ & $660-<880$ & $\geq 880$ \\
\hline
\end{tabular}




\begin{tabular}{|c|c|c|c|c|c|c|c|}
\hline \multirow{3}{*}{\multicolumn{2}{|c|}{ No. Parameter }} & \multicolumn{3}{|c|}{ Skala/ Skor } & \multirow{3}{*}{$\begin{array}{l}3 \\
\text { Sedang }\end{array}$} & \multirow{3}{*}{$\begin{array}{l}4 \\
\text { Tinggi }\end{array}$} & \multirow{3}{*}{$\begin{array}{l}5 \\
\text { Sangat tinggi }\end{array}$} \\
\hline & & \multirow{2}{*}{ Bobot } & & 2 & & & \\
\hline & & & Sangat rendah & Rendah & & & \\
\hline 4 & Jumlah genera & 3 & $1-2$ & $3-5$ & $6-7$ & $8-10$ & $11-12$ \\
\hline 5 & Tipe substrat & 1 & $\begin{array}{l}\text { Pasir } \\
\text { Berkarang }\end{array}$ & Pasir & $\begin{array}{l}\text { Pasir } \\
\text { Berlumpur }\end{array}$ & $\begin{array}{l}\text { Lumpur } \\
\text { Berpasir }\end{array}$ & Berlumpur \\
\hline 6 & $\begin{array}{l}\text { Jarak dari aktivitas } \\
\text { Manusia }(\mathrm{km})\end{array}$ & 1 & $<0,5$ & $>0,5-1$ & $>1-4$ & $>4-5$ & $>5$ \\
\hline
\end{tabular}

Ket. $\mathrm{N}_{\max }: 90$.

Pengukuran Indeks dimensi mangrove dilakukan dengan cara, mengukur lebar mangrove dari garis pantai ke arah laut (vertikal), serta pungukran panjang yang diukur sejajar garis pantai (Horizontal), yang telah didigitasi dengan bantuan Analisis GIS, menggunakan software ArcMap 10.1, berdasarkan pada Citra Sentinel 2, tahun 2017. Pembagian dimensi lebar dan panjang berdasarkan pada kemiripan lebar suatu bagian pada ekosistem mangrove (Subur, 2012; Subur, 2013). Selanjutnya dimensi-dimensi tersebut, dinilai berdasarkan matriks nilai dimensi mangrove, Tabel 2. Identifikasi spesies dan genera mangrove menggunakan pedoman, Noor et al., (2012), spesies dominan, menggunakan analisis indeks dominasi menurut Odum, (1996). Penilaian kondisi lingkungan (substrat), dilakukan secara insitu. Perhitungan jumlah individu per hektar (ha) menggunakan metode line transek dan kuadrat berukuran 10x10 m², Chapman, 1976; Tomlinson,
1986; English et al., 1994; Kusmana, 1997; Bengen, 2000). Karena luasan ekosistem mangrove yang terbatas (sempit), serta keraptan individu yang rendah, terutama untuk kategori anakan dan semaian, maka ukura kuadrat yang digunakan adalah sama dengan ukuran kuadrat untuk kategori pohon yaitu $10 \times 10 \mathrm{~m}^{2}$, dengan maksud untuk memperbesar peluang ditemukannya mangrove kategori anakan dan semaian. Luas areal yang disampling dengan kuadrat yaitu $900 \mathrm{~m}^{2}$. Pengukuran jarak ekosistem mangrove dari pemukiman penduduk $(\mathrm{km})$, dilakukan dengan analisis GIS, berdasarkan citra Satelit Sentinel 2 tahun 2017.

Tabel 2. Matriks nilai dimensi lebar dan panjang ekosistem mangrove (Subur, 2012)

\begin{tabular}{lcccccccccc}
\hline JARAK & $\mathbf{0 . 0 1}$ & $\mathbf{0 . 0 2}$ & $\mathbf{0 . 0 3}$ & $\mathbf{0 . 0 4}$ & $\mathbf{0 . 0 5}$ & $\mathbf{0 . 0 6}$ & $\mathbf{0 . 0 7}$ & $\mathbf{0 . 0 8}$ & $\mathbf{0 . 0 9}$ & $\mathbf{0 . 1}$ \\
L/V (m) & $0-10$ & $11-20$ & $21-30$ & $31-40$ & $41-50$ & $51-60$ & $61-70$ & $71-80$ & $81-90$ & $91-100$ \\
& & & & & & & & & $961-$ & \\
P/H (m) & $0-120$ & $121-240$ & $241-360$ & $361-480$ & $481-600$ & $601-720$ & $721-840$ & $841-960$ & 1080 & $1080-1200$ \\
JARAK & $\mathbf{0 . 1 1}$ & $\mathbf{0 . 1 2}$ & $\mathbf{0 . 1 3}$ & $\mathbf{0 . 1 4}$ & $\mathbf{0 . 1 5}$ & $\mathbf{0 . 1 6}$ & $\mathbf{0 . 1 7}$ & $\mathbf{0 . 1 8}$ & $\mathbf{0 . 1 9}$ & $\mathbf{0 . 2}$ \\
L/V (m) & $101-110$ & $111-120$ & $121-130$ & $131-140$ & $141-150$ & $151-160$ & $161-170$ & $171-180$ & $181-190$ & $191-200$ \\
& $1201-$ & $1321-$ & $1441-$ & $1561-$ & $1681-$ & $1801-$ & $1921-$ & $2041-$ & $2161-$ & \\
P/H (m) & 1320 & 1440 & 1560 & 1680 & 1800 & 1920 & 2040 & 2160 & 2280 & $2281-2400$ \\
JARAK & $\mathbf{0 . 2 1}$ & $\mathbf{0 . 2 2}$ & $\mathbf{0 . 2 3}$ & $\mathbf{0 . 2 4}$ & $\mathbf{0 . 2 5}$ & $\mathbf{0 . 2 6}$ & $\mathbf{0 . 2 7}$ & $\mathbf{0 . 2 8}$ & $\mathbf{0 . 2 9}$ & $\mathbf{0 . 3}$ \\
L/V (m) & $201-210$ & $211-220$ & $221-230$ & $231-240$ & $241-250$ & $251-260$ & $261-270$ & $271-280$ & $281-290$ & $291-300$ \\
& $2401-$ & $2521-$ & $2641-$ & $2761-$ & $2881-$ & $3001-$ & $3121-$ & $3241-$ & $3361-$ & \\
P/H (m) & 2520 & 2640 & 2760 & 2880 & 3000 & 3120 & 3240 & 3360 & 3480 & $3481-3600$ \\
JARAK & $\mathbf{0 . 3 1}$ & $\mathbf{0 . 3 2}$ & $\mathbf{0 . 3 3}$ & $\mathbf{0 . 3 4}$ & $\mathbf{0 . 3 5}$ & $\mathbf{0 . 3 6}$ & $\mathbf{0 . 3 7}$ & $\mathbf{0 . 3 8}$ & $\mathbf{0 . 3 9}$ & $\mathbf{0 . 4}$ \\
L/V (m) & $301-310$ & $311-320$ & $321-330$ & $331-340$ & $341-350$ & $351-360$ & $361-370$ & $371-380$ & $381-390$ & $391-400$ \\
& $3601-$ & $3721-$ & $3841-$ & $3961-$ & $4081-$ & $4201-$ & $4321-$ & $4441-$ & $4561-$ & \\
P/H (m) & 3720 & 3840 & 3960 & 4080 & 4200 & 4320 & 4440 & 4560 & 4680 & $4681-4800$ \\
JARAK & $\mathbf{0 . 4 1}$ & $\mathbf{0 . 4 2}$ & $\mathbf{0 . 4 3}$ & $\mathbf{0 . 4 4}$ & $\mathbf{0 . 4 5}$ & $\mathbf{0 . 4 6}$ & $\mathbf{0 . 4 7}$ & $\mathbf{0 . 4 8}$ & $\mathbf{0 . 4 9}$ & $\mathbf{0 . 5}$ \\
L/V (m) & $401-410$ & $411-420$ & $421-430$ & $431-440$ & $441-450$ & $451-460$ & $461-470$ & $471-480$ & $481-490$ & $491-500$ \\
P/H (m) & $4801-$ & $4921-$ & $5041-$ & $5161-$ & $5281-$ & $5401-$ & $5521-$ & $5641-$ & $5761-$ & $5881-6000$ \\
\hline
\end{tabular}




\begin{tabular}{lcccccccccc}
\hline & & & & & & & & & \\
\hline & 4920 & 5040 & 5160 & 5280 & 5400 & 5520 & 5640 & 5760 & 5880 & $\mathbf{0 . 6}$ \\
JARAK & $\mathbf{0 . 5 1}$ & $\mathbf{0 . 5 2}$ & $\mathbf{0 . 5 3}$ & $\mathbf{0 . 5 4}$ & $\mathbf{0 . 5 5}$ & $\mathbf{0 . 5 6}$ & $\mathbf{0 . 5 7}$ & $\mathbf{0 . 5 8}$ & $\mathbf{0 . 5 9}$ & $\mathbf{0}$ \\
L/V (m) & $501-510$ & $511-520$ & $521-530$ & $531-540$ & $541-550$ & $551-560$ & $561-570$ & $571-580$ & $581-590$ & $591-600$ \\
& $6001-$ & $6121-$ & $6241-$ & $6361-$ & $6481-$ & $6601-$ & $6721-$ & $6841-$ & $6961-$ & \\
P/H (m) & 6120 & 6240 & 6360 & 6480 & 6600 & 6720 & 6840 & 6960 & 7080 & $7081-7200$ \\
JARAK & $\mathbf{0 . 6 1}$ & $\mathbf{0 . 6 2}$ & $\mathbf{0 . 6 3}$ & $\mathbf{0 . 6 4}$ & $\mathbf{0 . 6 5}$ & $\mathbf{0 . 6 6}$ & $\mathbf{0 . 6 7}$ & $\mathbf{0 . 6 8}$ & $\mathbf{0 . 6 9}$ & $\mathbf{0 . 7}$ \\
L/V (m) & $601-610$ & $611-620$ & $621-630$ & $631-640$ & $641-650$ & $651-660$ & $661-670$ & $671-680$ & $681-690$ & $691-700$ \\
& $7201-$ & $7321-$ & $7441-$ & $7561-$ & $7681-$ & $7801-$ & $7921-$ & $8041-$ & $8161-$ & \\
P/H (m) & 7320 & 7440 & 7560 & 7680 & 7800 & 7920 & 8040 & 8160 & 8280 & $8281-8400$ \\
JARAK & $\mathbf{0 . 7 1}$ & $\mathbf{0 . 7 2}$ & $\mathbf{0 . 7 3}$ & $\mathbf{0 . 7 4}$ & $\mathbf{0 . 7 5}$ & $\mathbf{0 . 7 6}$ & $\mathbf{0 . 7 7}$ & $\mathbf{0 . 7 8}$ & $\mathbf{0 . 7 9}$ & $\mathbf{0 . 8}$ \\
L/V (m) & $701-710$ & $711-720$ & $721-730$ & $731-740$ & $741-750$ & $751-760$ & $761-770$ & $771-780$ & $781-790$ & $791-800$ \\
& $8401-$ & $8521-$ & $8641-$ & $8761-$ & $8881-$ & $9001-$ & $9121-$ & $9241-$ & $9361-$ & \\
P/H (m) & 8520 & 8640 & 8760 & 8880 & 9000 & 9120 & 9240 & 9360 & 9480 & $9481-9600$ \\
JARAK & $\mathbf{0 . 8 1}$ & $\mathbf{0 . 8 2}$ & $\mathbf{0 . 8 3}$ & $\mathbf{0 . 8 4}$ & $\mathbf{0 . 8 5}$ & $\mathbf{0 . 8 6}$ & $\mathbf{0 . 8 7}$ & $\mathbf{0 . 8 8}$ & $\mathbf{0 . 8 9}$ & $\mathbf{0 . 9}$ \\
L/V (m) & $801-810$ & $811-820$ & $821-830$ & $831-840$ & $841-850$ & $851-860$ & $861-870$ & $871-880$ & $881-890$ & $891-900$ \\
& $9601-$ & $9721-$ & $9841-$ & $9961-$ & $10081-$ & $10201-$ & $10321-$ & $10441-$ & $10561-$ & $10681-$ \\
P/H (m) & 9720 & 9840 & 9960 & 10080 & 10200 & 10320 & 10440 & 10560 & 10680 & 10800 \\
JARAK & $\mathbf{0 . 9 1}$ & $\mathbf{0 . 9 2}$ & $\mathbf{0 . 9 3}$ & $\mathbf{0 . 9 4}$ & $\mathbf{0 . 9 5}$ & $\mathbf{0 . 9 6}$ & $\mathbf{0 . 9 7}$ & $\mathbf{0 . 9 8}$ & $\mathbf{0 . 9 9}$ & $\mathbf{1}$ \\
L/V (m) & $901-910$ & $911-920$ & $921-930$ & $931-940$ & $941-950$ & $951-960$ & $961-970$ & $971-980$ & $981-990$ & $991->1000$ \\
& $10801-$ & $10921-$ & $11041-$ & $11161-$ & $11281-$ & $11401-$ & $11521-$ & $11641-$ & $11761-$ & $11881-$ \\
P/H (m) & 10920 & 11040 & 11160 & 11280 & 11400 & 11520 & 11640 & 11760 & 11880 & $>12000$ \\
\hline
\end{tabular}

Catatan: Matriks ini hanya diperuntukkan untuk pulau Kecil-Mikro, dengan panjang garis pantai $\leq 12.000$ meter (12 km). L/V= Lebar / Vertikal (Tegak Lurus Garis Pantai); P/H=Panjang / Horizontal (Sejajar Garis Pantai).

\section{Analisis Data}

Analisis indeks dimensi mangrove menggunakan formula yang dikemukakan oleh Subur (2012; Subur, 2017), sebagai berikut:

$\operatorname{IDMg}=\sum\left[\frac{\mathrm{NL}}{\mathrm{NP}}\right]+\sum\left[\frac{\mathrm{NP}}{\mathrm{SP}}\right]$

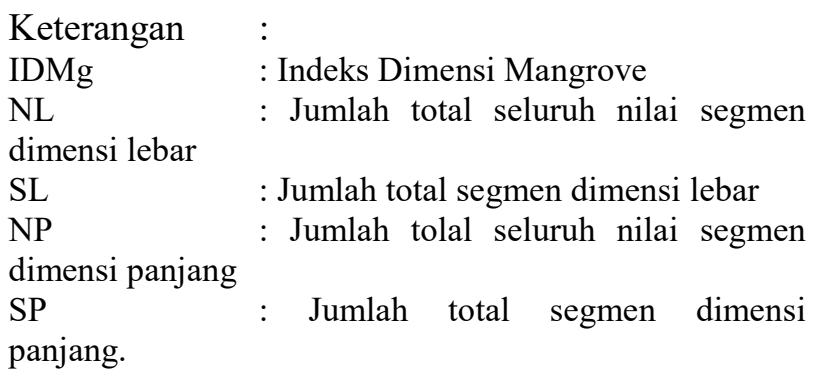

Nilai IDMg, berkisar antara 0-2.

Dengan kriteria sebagai berikut :

Sangat Rendah : $(0,0 \leq \mathrm{IDMg} \leq 0,4)$

Rendah $\quad:(0,4 \leq \mathrm{IDMg} \leq 0,8)$

Sedang $\quad:(0,8 \leq \mathrm{IDMg} \leq 1,2)$

Tinggi $\quad:(0,2 \leq \mathrm{IDMg} \leq 0,6)$

Sangat Tinggi $:(1,6 \leq \mathrm{IDMg} \leq 2,0)$
Analisis dominasi spesies menggunakan formula yang dikemukan oleh Odum (1996), sebagai berikut;

$\mathrm{C}=\sum\left(\frac{n_{i}}{N}\right)^{2}$

Analisis kapasitas adaptif ekosistem mangrove menggunakan formula yang dikemukakan oleh Subur, 2012; Subur, 2013: Subur, 2017), sebagai berikut;

$\operatorname{KpMg}=\sum\left[\frac{\mathrm{N}_{\mathrm{i}}}{\mathrm{N}_{\max }}\right]$.

Keterangan

$\mathrm{KpMg} \quad$ : Kapasitas Mangrove

$\mathrm{Ni} \quad$ : Total Nilai Parameter Hasil

Pengukuran

$\mathrm{N}_{\max } \quad$ : Nilai maksimum.

Nilai KpMg, berkisar antara 0-1.

Dengan kriteria sebagai berikut :

Sangat Rendah : $0,0 \leq \mathrm{KpMg} \leq 0,2$ )

Rendah $\quad: 0,2 \leq \mathrm{KpMg} \leq 0,4)$

Sedang $\quad: 0,4 \leq \mathrm{KpMg} \leq 0,6)$

Tinggi $: 0,6 \leq \mathrm{KpMg} \leq 0,8)$

Sangat Tinggi $: 0.8 \leq \mathrm{KpMg} \leq 1,0)$ 


\section{Hasil dan Pembahasan}

Ekosistem mangrove di pulau Maitara, ditemukan menyebar secara sempit pada bagian Utara dan Selatan. Berdasarkan hasil anlisis GIS luas mangrove di pulau Maitara adalah 6,74 hektar (ha), yang terdiri dari 0,74 ha tumbuh di bagian utara barat laut serta 5,75 hektar tumbuh pada bagian selatan tenggara, (Gambar 1).

Ekosistem mangrove di pulau ini berada diantara pemukiman penduduk, sehingga cenderung tertekan oleh aktivitas antropogenik. Topografi pulau Maitara yang bergunung, memiliki dataran rendah yang relatif terbatas atau sempit, menyebabkan konvesi lahan mangrove menjadi pemukiman, penimbunan untuk perluasan jalan, menjadi salah satu penyebab tertekannya ekosistem mangrove di pulau ini. Setyawan et al., (2002), mengemukakan bahwa kebanyakan habitat mangrove sudah dikonversi menjadi lahan tambak atau pemukiman. Selanjutnya Onrizal, (2010), menjelaskan bahwa kawasan dengan aktivitas masyarakat yang tinggi dapat menyebabkan aberasi, penurunan tangkapan perikanan pantai, intrusi air laut yang semakin jauh ke arah daratan. Limbah rumah tangga serta pengaruh industri turut perperan dalam menurunkan kualitas lingkungan ekosistem mangrove di wilayah pesisir (Tam dan Wong, 1995; Tam dan Wong, 1997; Yu et al., 1977). Mangrove ditebang dan dibersihkan secara ekstensif untuk membuat jalan bagi budidaya air payau serta pembangunan infrastruktur (Walters et al., 2008). Tekanan penduduk biasanya tersebar sepanjang pantai, sehingga sedikit mengejutkan bahwa pengaruh manusia terhadap ekosistem hutan mangrove adalah signifikan dan terus berkembang. Mengrove telah dibersihkan dan terdegradasi pada skala mengkhawatirkan selam empat dekade terakhir (Valiela et al., 2001; Wilkie dan Fortuna, 2003; Duke et al., 2007).

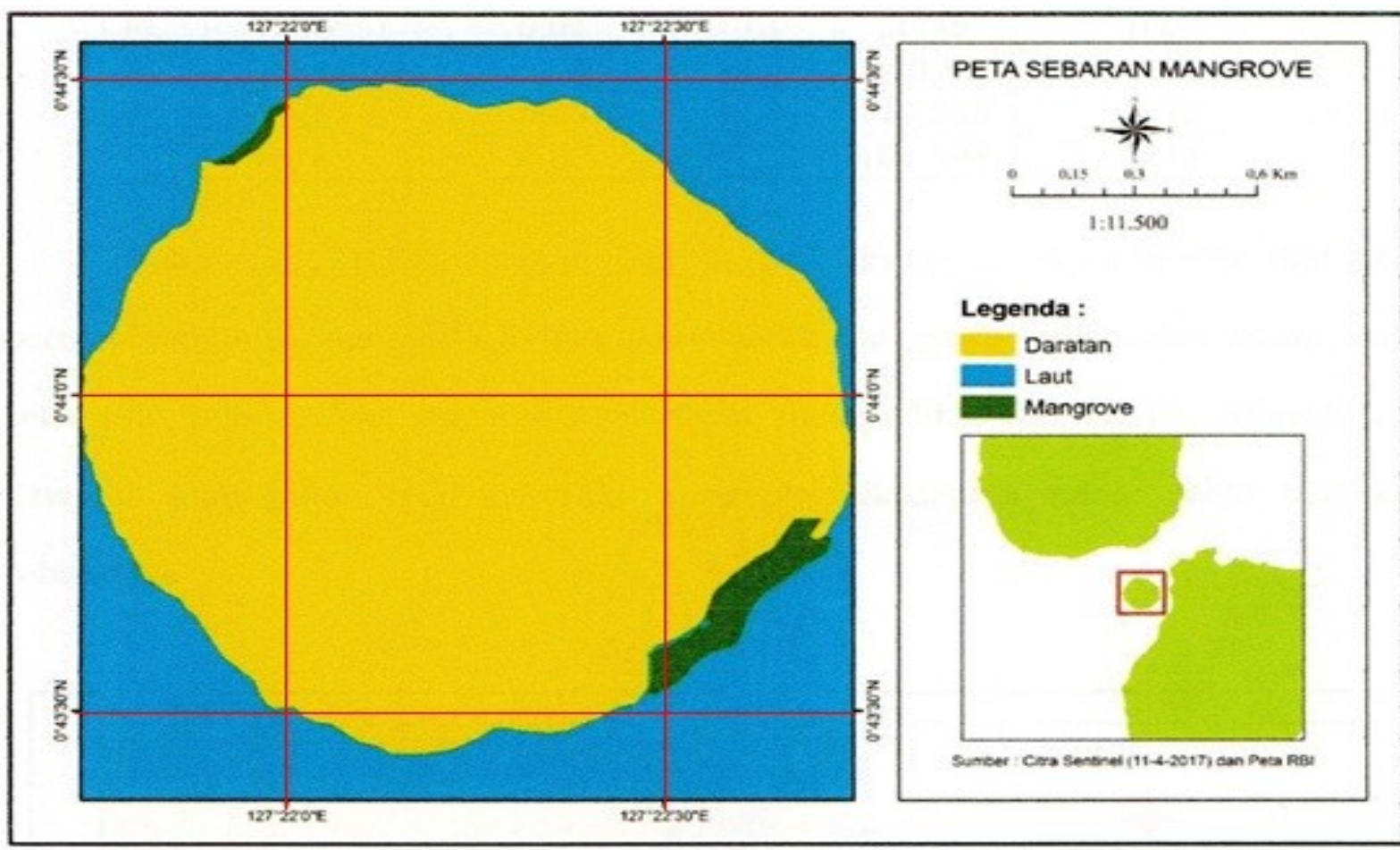

Gambar 2. Peta Sebaran Mangrove di Pesisir P. Maitara

\section{Indeks Dimensi Mangrove (IDMg)}

Pengukuran dimensi ekosistem mangrove di P. Maitara, menunjukkan bahwa panjang ratarata sejajar garis pantai yaitu 866,22 meter, serta lebar maksimal 113,53 meter. Rincian pengukuran tersebut ditampilkan pada Tabel 3. Subur (2012), menyatakan bahwa, pengukuran indeks dimensi bermanfaat untuk mengetahui laus penyebaran 
mangrove pada suatu pulau kecil, selain itu nilai indeks dimensi dapat mengindikasikan bahwa satu kawasan pulau kecil memiliki penyebaran ekosistem mangrove yang laus atau sempit.

Tabel 3. Hasil pengukuran dan Analisis indeks dimensi mangrove di P. Maitara.

\begin{tabular}{llllll}
\hline No. Panjang & $\begin{array}{l}\text { Nilai Dimensi } \\
\text { Panjang }\end{array}$ & No. Lebar & $\begin{array}{l}\text { Nilai Dimensi } \\
\text { Lebar }\end{array}$ \\
\hline $\mathrm{P}_{1}$ & 57,7 & 0,01 & $\mathrm{~L}_{1}$ & 18,94 & 0,02 \\
$\mathrm{P}_{2}$ & 165,01 & 0,02 & $\mathrm{~L}_{2}$ & 26,19 & 0,03 \\
$\mathrm{P}_{3}$ & 41,79 & 0,01 & $\mathrm{~L}_{3}$ & 20,48 & 0,02 \\
$\mathrm{P}_{4}$ & 219,53 & 0,03 & $\mathrm{~L}_{4}$ & 110,57 & 0,11 \\
$\mathrm{P}_{5}$ & 337,62 & 0,03 & $\mathrm{~L}_{5}$ & 113,53 & 0,12 \\
$\mathrm{P}_{6}$ & 50,09 & 0,01 & $\mathrm{~L}_{6}$ & 101,69 & 0,11 \\
\hline
\end{tabular}

Hasil analisis dimensi mangrove di $\mathrm{P}$. Maitara diperoleh nilai indeks dimensi sebesar 0,086. Nilai tersebut tergolong pada kategori "sangat rendah", hal tersebut didukung oleh data sebagaimana tabel di atas, yang menunjukkan bahwa ekosistem mangrove P. Maitara memiliki penyebaran yang sempit. Lebar mangrove di P. Maitara antara 18,94 - 113,53 meter, dengan lebar rata-rata 65,23 meter. Nilai indeks dimensi mangrove ini akan semakin tinggi, jika ekosistem tersebut tersebar luas pada seluruh pesisir suatu pulau kecil (Subur, 2012; Subur et al., 2013 Subur, 2017). Subur (2012), menemukan bahwa nilai indeks dimensi pulau-pulau kecil di gugusan pulau Guraici, tergolong pada kategori "sangat rendah", selanjutnya dikatakan bahwa penyebaran mangrove di pulau-pulau kecil tersebut sempit.

\section{Spesies Dominan}

Berdasarkan hasil identifikasi dan analisis yang dilakukan, ditemukan sebanyak 4 spesies mangrove yang tumbuh di P. Maitara, terdiri dari Soneratia alba, Rhizophora apiculata, $R$. mucronata, dan $R$. stylosa. Hasil analisis indeks dominasi, mangarah kepada dominasi sedang, hal tersebut ditunjukkan oleh nilai indeks sebesar 0,57 , dalam hal ini $R$. apiculata, cenderung lebih mengarah pada spesies yang dominan. Hal tersebut sejalan dengan penelitian sebelum oleh Subur (2012), yang menemukan bahw $R$. apiculata, tumbuh dominan pada pulau-pulau kecil di gugusan pulau Guraici. Kondisi tersebut, menunjukkan bahwa spesies tersebut memiliki kemampuan untuk beradaptasi terhadap terbatasnya faktor-faktor pembatas, seperti terbatasnya pasokan air tawar, nutrien serta stabilitas substrat di pulau kecil (Subur, 2012).

Tabel 4. Indeks Dominasi Vegetasi Mangrove di P. Maitara

\begin{tabular}{lll}
\hline No. & Spesies & Indeks Dominasi (C') \\
\hline 1 & Rhizophora apiculata & 0,14 \\
2 & Soneratia alba & 0,23 \\
3 & Rhizophora mucronata & 0,11 \\
4 & Rhizophora stylosa & 0,09 \\
\multicolumn{2}{l}{ Total : } & 0,57 \\
\hline
\end{tabular}

\section{Kerapatan Pohon per Hektar (ha)}

Hasil analisis kerapatan pohon per hektar, menunjukkan bahwa total seluruh indivitu 2,022 ind/ha, terdiri atas $789 \mathrm{ind} /$ ha kategori pohon; 433,4 ind/ ha, kategori anakan; $799.6 \mathrm{ind} / \mathrm{ha}$ kategori semayan. Distribusi jumlah individu setiap spesies, ditampilkan Tabel berikut.

Tabel 5. Kerapatan Pohon Mangrove per hektar di P. Maitara

\begin{tabular}{lll}
\hline No. & Spesies & Pohon/ha \\
\hline 1. & Rhizophora apiculata & 255,6 \\
2. & Sonneratia alba & 200,0 \\
3. & Rhizophora mucronata & 177,8 \\
4. & Rhizophora stylosa & 155,6 \\
Total : & & 789,0 \\
\hline
\end{tabular}

Berdasarkan Tabel di atas, terlihat bahwa kerapatan pohon, tergolong pada kategori "sedang", kondisi tersebut disebabkan luas kawasan untuk tumbuh mangrove yang sempit, selain itu terbatasnya pasokan air tawar. Kelangsungan hidup serta pertumbuhan mangrove ditentukan oleh tiga faktor utama, yaitu suplai air tawar dan salinitas, pasokan nutrien serta stabilitas substrat, perairan yang tenang, terlindung dari arus pasang surut yang kencang (Dahuri, 2003; Bengen, 2004). P. Maitara sebagai pulau kecil-mikro, sumber air tawar hanya bergantung pada air hujan, sedangkan untuk kebutuhan penduduk, disediakan oleh perusahaan air minum daerah (PDAM) dari pulau Tidore, melalui pipa bawah laut yang melintasi selat antara P. Tidore dan P. Maitara.

\section{Jumlah genera}

Hasil penelitian ini diperoleh sebanyak 2 genera mangrove di P. Maitara, yaitu Rhizopora dan Sonneratia. Odum (1996), menyatakan bahwa 
kelompok tumbuhan yang dominan pada hutan mangrove adalah spesies bakau dari famili Rhizophoraceae seperti $R$. mucronata, $R$. apiculata. Selain itu Khairijon (1998), mengatakan bahwa pada umumnya struktur yang terbesar dari mangrove di Indonesia diisi oleh Rhizophora sp. Nybakken (1992), mengemukakan bahwa daur hidup yang khusus dari spesies bakau (Rhizophora sp) dengan benih yang dapat berkecambah pada waktu masih berada pada tumbuhan induk sangat menunjuang proses distribusi yang luas dari spesies tersebut pada ekosistem mangrove.

\section{Tipe Substrat}

Mangrove di pulau Maitara, ditemukan tumbuh pada substrat "lumpur berpasir". Salah satu sifat mangrove, yaitu akan tumbuh dengan baik pada wilayah pesisir dengan substrat yang stabil, terlindung, perairan yang tenang (Subur, 2012; Subur et al., 2013; Nybakken, (1992); Bengen, (2002); Dahuri, (2003). Selain itu vegetasi mangrove juga mengembangkan pola adaptasi secara morfologi dan fisiologi untuk hidup pada daerah pasang surut (Intertidal).

Pola adaptasi yang dikembangkan oleh vegetasi mangrove terhadap lingkungan pasang surut yang mudah dikenali adalah sistem akar udara. Fungsi utamanya yaitu untuk pertukaran gas, memperkokoh tegaknya batang pada daerah lumpur serta penyerapan unsur hara, misalnya akar udara pada Avicennia spp, akar pancang pada Sonneratia spp, akar lutut pada Bruguieria spp, akar papan pada Xylocarpus spp, dan akar tunjang pada Rhizophora spp (Tomlinson, 1986).

\section{Jarak ekosistem dari pemukiman penduduk (Km)}

Hasil pengukuran jarak ekosistem mangrove dari pemukiman penduduk di pulau Maitara berkisar antara $0,05 \mathrm{~km}-0,25 \mathrm{~km}$ (50250 meter), yang berarti bahwa ekosistem tersebut berada sangat dekat dengan aktivitas yang dilakukan oleh masyarakat setempat. Alger et al., (2002), mengemukakan bahwa suatu sumberdaya yang semakin dekat dengan pusat aktivitas masyarakat ataupun pemukiman penduduk, maka sumberdaya tersebut akan semakin rentan, dan sebaliknya semakin jauh suatu sumberdaya dari pusat kegiatan masyarakat atau pemukiman penduduk, maka sumberdaya tersebut akan semakin terjaga kelestariannya. Alger et al., (2002), menyatakan bahwa keterisolasian sangat penting bagi manusia dan keanekaragaman hayati (Biodiversitas), karena ketidak terisolasian dari manusia, sering menimbulkan ancaman dan prosesproses yang menyebabkan kepunahan dari banyak spesies. Sebagai pulau kecil mikro, penduduk di pulau Maitara, seluruhnya mendiami wilayah pesisir dan mempengaruhi ekosistem mangrove. Tekanan penduduk biasanya tersebar sepanjang pantai, sehingga menyebabkan mangrove terdegradasi dalam skala yang mengkhawatirkan selama beberapa dekade terhakhir (Valiela et al., 2001); Wilkie and Fortuna 2003; Duke et al., 2007).

\section{Kapasitas Adaptif Ekosistem Mangrove Di Pulau Maitara}

Berdasarkan hasil analisis setiap komponen, ekosistem mangrove di pesisir pulau Maitara memiliki nilai Kapasitas Adaptif sebesar 0,44 . Nilai tersebut tergolong pada kategori "Sedang", hal tersebut mengindikasikan bahwa ekosistem mangrove di pulau tersebut memiliki penyebaran yang sempit (Subur, 2012). Kondisi tersebut disebabkan karena mangrove memiliki ketergantungan tinggi terhadap kebutuhan substrat yang sesuai untuk tumbuh dan berkembang secara optimal, sebagaiman biasa ditemukan pada ekosistem mangrove di pulau besar (Nybakken, 1992). Sedangkan dipulau kecil seperti pulau Maitara, ketersediaan substrat yang sesuai untuk pertumbuhan mangrove sangat terbatas. Penelitian yang dilakukan Subur (2012), menemukan bahwa kapasitas adaptif mangrove di gugus P. Guraici, umumnya tergolong sedang. Keterbatasan ruang pesisir yang sesuai untuk mendukung pertumbuhan mangrove di pulau kecil, menyebabkan terbatasnya penyebaran mangrove (Subur, 2017). Tabel berikut menampilkan hasil analisis komponen kapasitas adaptif mangrove di P. Maitara. 
Tabel 6. Hasil Analisis Kapasitas Adaptif Ekosistem Mangrove di P. Maitara

\begin{tabular}{llllllll}
\hline \multirow{2}{*}{ Lokasi } & PARAMETER & & & & KAEM & Kategori \\
& IDMg & SMD & KPPH & JLG & TS & & \\
\hline P. Maitara & 0,086 & R. apiculata & 789 & 2 & LB & 0,44 & Sedang \\
\hline
\end{tabular}

Ket. $\mathrm{IDMg}=$ Ideks Dimensi Mangrove. $\mathrm{SMD}=$ Spesies Mangrove Dominan. KPPH=Kerapatan Pohon per Hektar. JLG=Jumlah Genera. TS=Tipe Substrat. KAEM=Kapasitas Adaptif Ekosistem Mangrove. $\mathrm{KTG}=$ Kategri. $\mathrm{LB} .=$ Lumpur Berpasir

Nilai kapasitas adapatif ekosistem mangrove dapat menunjukkan peranannya terhadap perlindungan suatu pulau kecil mikro, sehigga apabila semakin rendah nilai tersebut, maka peranan ekosistem tersebut juga rendah, dan sebaliknya apabila nilai kapasitas adaptif tinggi, maka peranannya akan tinggi (Subur, 2012). Ekosistem mangrove dengan kapasitas yang tinggi, berperan penting dalam mereduksi energi gelombang, efektif sebagai perangkap sedimen, serta memperlambat proses erosi pantai (Othman, 1994).

\section{Kesimpulan}

Berdasarkan hasil penelitian ini dapat disimpulkan bahwa kapasitas adaptif ekosistem mangrove di Pulau Maitara tergolong "sedang".

\section{Ucapan Terimakasih}

Terimakasih yang sebesar-besarnya kami sampaikan kepada LPPM-Unkhair, atas dukungan dana, sehingga penelitian ini dapat dilaksanakan. Kepada semua pihak yang turut mendukung penelitian ini, kamu ucapkan terimakasih yang tak terhingga.

\section{Daftar Pustaka}

Alongi, D.M. 2002. Present state and future of the world's mangrove forests. J. Environmental Conservation. 29:331-349.

Alongi, D.M., 2008. Mangrove forests: resilience, protection from tsunamis, and responses to global climate change. Estuar. Coast. Shelf Sci. 76,1-13.

Alger, D.A, Burbidge, A.A, Angus, G.J. 2002. Cateradication an Hermit Island, Montebello Islands, Western Australia. In:
Turning the tide: The eradication of island Invasive Species. CR Veitch and MN Clout (eds.), IUCN SSC Invasive Species Specialist Group, IUCN, Gland, pp. 14-18.

Barbier, E.B., Hacker, S.D. Kennedy, C., Koch, E.W. Stier, A.C., Sillimin, B.R. 2011. The value of estuarine and coastal ecosystem services. Ecol. Monogr. 81 (2). 169-193.

Bayen, S. 2012. Occurrence bioavailability and toxic effect of trace metals and organic contaminants in mangrove ecosystems: A riview Environ. Int., 48. Pp. 84-101.

Bengen, D.G. 2000. Teknik pengambilan contoh dan analisis data biofisik sumberdaya pesisir. Pusat kajian sumberdaya pesisir dan lautan. Fakultas perikanan dan ilmu kelautan. Institut pertanian Bogor. Bogor.

Bengen DG. 2002. Pengembangan Konsep Daya Dukung Dalam Pengelolaan Lingkungan Pulau-Pulau Kecil. Laporan Akhir Kerjasama Antara Kantor Menteri Negera Lingkungan Hidup dan Fakultas Perikanan dan Ilmu Kelautan IPB. Bogor.

Begen, D.G. 2004. Ekosistem dan Sumberdaya Alam Pesisir dan Laut serta Prinsip Pengelolaannya. Sinopsis. PKSPL-IPB. Bogor.

Castillo, J.A.A., Armando, A. Apan., Tek, N. Maraseni., Severino G. Salmo III. 2017. Soil Greenhouse gas fluzes in tropical mangrove forests and in land uses on deforested mangrove lands. Catena. 159:60-69.

Chapman, V. J. 1976. Mangrove vegetation. J. Cramer, Inder A.R. Gantner Verlag Kommandit gesellschaft, FL-9490 VUDUZ.

Duke, N.C. Meyneeke, J.O., Ditmann, S., Ellison, A.M., Anger, K., Barger, U., Cannicci, S Diele. K., Ewel, K.C., Field, C.D., Kaedam, N., Lee, S.Y., Marchand, C., 
Nordhaus, I., Dahdouh-Guebas, F. 2007. A world without mangrove ?. Science. 317. 41-41.

Dahuri, R. 2003. Keanekaragaman Hayati Laut: Aset pembagunan berkelanjutan Indonesia. Gramedia. Jakarta.

English, S., C. Wilkinson, V. Baker. 1994. Survey manual for tropical marine resources. Australian Institute of Marine science. Townsville.

FAO. 2007. The world's mangrove 1980-2005. FAO Forestry paper 153. Food and Agriculture Organization of the united nations, Rome.

Fussel, H.M., Klein. 2006. Climate Change Vulnerability Assessments: An Evolution of Conseptual Thinking. J. Climat change. 75: 301-329.

Gallopin, G.C. 2006. Linkages beetwin Vulnerability, Resiliensi and Adaptive Capacity. Global Environmental Change. 16:293-303.

Kathiresan, K., Bingham, B.L. 2001. Biology of mangroves and mangrove ecosystems. Advances in marine biology. 40: 81-251.

Koch, E.W., Barbier, E.B., Silliman, B.R., Reed, D.J., Perillo, G.M.E., Hacker, S.D., Granek, E.F., Primavera, J.H., Muthiga, N., Polasky, S., Halpern, B.S., Kennedy, C.J., Kappel, C.V., Wolanski, E. 2009. NonLinearity in ecosystem services: temporal and spatial variability in coastal protection. Front. Ecol. Environ. 7 (1). 29-37.

Kusmana, C. 1997. Metode survei vegetasi. IPBPress. Bogor.

Luers, A.L. 2005. The Surface of Vulnerability: An Analytical Framwork Framework for Examming Environmental Change. J. Global Environmental Change. 15: 214223.

Manson, R.A., Loneragam, N.R., Skilleter, G.A., Phinn, S.R. 2005. An evaluation of the evidence for linkages between mangroves and fisheries: a synthesis of literature and identification of research directions. Oceanography and marine biology: an Annual Review. 43: 483-513.

Mazda, Y., Wolanski, E., Ridd, P.V. 2007. The Role of Physical Processes in mangrove environmental change: Manual for the preservation and utilization of mangrove ecosystems. Terapub. Tokyo. Pp. 3-64.

Mimura, N. 1999. Vulnerability of Island Countries in the South Pacific to Sea Leve Rise and Climate Change. J. Climate Change Research. 12:56-62.

Moberg, F., Ronnback, P., 2003. Ecosystem services of the tropical seascape: interactions, substitutions and restoration. Ocean coast. Manage. 46, 27-46.

Moberg, F., Folke, C. 1999. Ecologycal Goods and Services of Coral Reef Ecosystems. J. Ecological Economics. 22:215-233.

Noor, Y.R., M. Khazali, I.N.N. Suryadiputra. 2012. Panduan pengenalan mangrove di Indonesia. Bogor: Wetlands international Indonesia Programme.

Nybakken, J.W. 1992. Biologi Laut: Suatu pendekatan Ekologi. PT. Gramedia. Jakarta

Odum, E. P. 1996. Dasar-dasar Ekologi. Terjemahan Samigan dan B. Srigadi. Gajah Mada Univ. Press. Yogyakarta.

Onrizal. 2010. Perubahan tutupan hutan mangrove di pantai timur sumatera utara periode 1977-2006. Jurnal Biologi Indonesia, 6 (2): 163-172.

Othman, M.A. 1994. Value of mangroves in coastal protection. J. Hydrobiologia. 285: 277-282.

Saenger, P. 2002. Mangrove ecology, Silviculture and conservation. SpringerScience+Bussines Media, B.V. Southern Cross University, Lismore. Australia. 360 pp.

Salom III, S., Lovelock, C., Duke, N. 2013. Vegetation and soil characteristics as indicators of restoration trajectories in restored mangroves. Hydrobiologia. 720 (1). 1-18.

Setyawan, A.D., A. Susilowati, Wiryanto. 2002. Habitat Reliks Vetasi mangrove di pantai selatan jawa. Biodiversitas. 3 (2): 242-256.

Subur, R. 2012. Daya Dukung Ekowisata Dengan Pendekatan Kapasitas Adaptif Ekologi di Pulau-Pulau Kecil (Kasus Gugus Pulau Guraici, Kabupaten Halmahera Selatan, Provinsi Maluku Utara). (Diseertation). Postgraduate Program. IPB. Bogor.

Subur, R., Yulianda., F. Fcahrudin A., Susilo, S.B. 2013. Kapasitas adaptif ekologis gugus Pulau Guraici. Kecamatan Kayoa, 
Kabupaten Halmahera Selatan. Provinsi Maluku Utara. J. Mairn Fisheries. IPB. Vol. 4. No. 2. 97-108.

Subur R. 2017. Penentuan Tingkat Kerentanan Pulau Guraici Berdasarkan Kapasitas Adaptif Ekosistem Pesisir. J. Biologi Tropis. Universitas Mataram. Vol. 17 (1). Hal. 1-14.

Subur, R. 2017. Kapasitas adaptif ekosistem mangrove di pulau-pulau kecil (studi gugugs pulau Guraici) Kabupaten Halmahera Selatan Propinsi Maluku Utara.Prosiding Seminar Nasional Kemaritiman dan Sumber Daya PulauPulau Kecil. Hal. 86-94.

Tam, N.F.Y., Y.S. Wong. 1995. Spatian and temporal variations of heavy metal contamination in sediments of a mangrove swamp in Hong Kong. Marine polution bulletin. 31: 254-261.

Tam, N.F.Y., Y.S. Wong, C.Y. Lu., R. Berry. 1997. Mapping and characterization of mangrove plant communities in Hong Kong. Hydrobiologia. 352: 25-37.

Tomlinson, C.B. 1986. The Botany of mangroves. Cambridge University Press. Cambridge.

Twilley, R.R., 1995. Properties of Mangrove ecosystems related to the energy signature of coastal environments. In: Hall, C.A.S. (Ed), Maximum Power: The Ideas and Applications of H.T. Odum. University of Corolado Press, Boulder. Pp. 43-62.

UNEP. 2014. The importance of mangrove to people: a call to action.

Valiela, I., Bowen, J.L., York, J.K. 2001. Mangrove forests: One of the world's threatened major tropical environments. BioSci. 51. 807-815.

Walters, B.B., Ronnback, P., Kovacs, J.M., Crona, B., Hussain, S.A., Badola, R., Primavera, , J.H., Barbier, E., Dahdouh-Guebas, F. 2008. Ethnobiology, Socio-economics and management of mangrove forests; a riview. Aquat. Bot. 89. 220-236.

Webb, E.L., Jachowski, N.R.A., Phelps, J., Friess, D.A., Than, M.M., Ziegler, A.D. 2014. Deforestation in the Ayeyarwady Delta and conservation implication of an internationally-engaged Myanmar. J.
Global Environmental Change. 24: 321333.

Wilkie, M.L., Fortuna, S. 2003. Status and Trends in mangrove area extent world wide. Working paper FRA 63, Forest Resources division, Forestry Department, UN-Food and Agriculture Organization. 292 pp.

Yu, Y., M. Shu., M.J. Steitz. 1997. A new method for detecting site of 2'-O-methylation in RNA molecules. RNA. 3: 324-331. 